
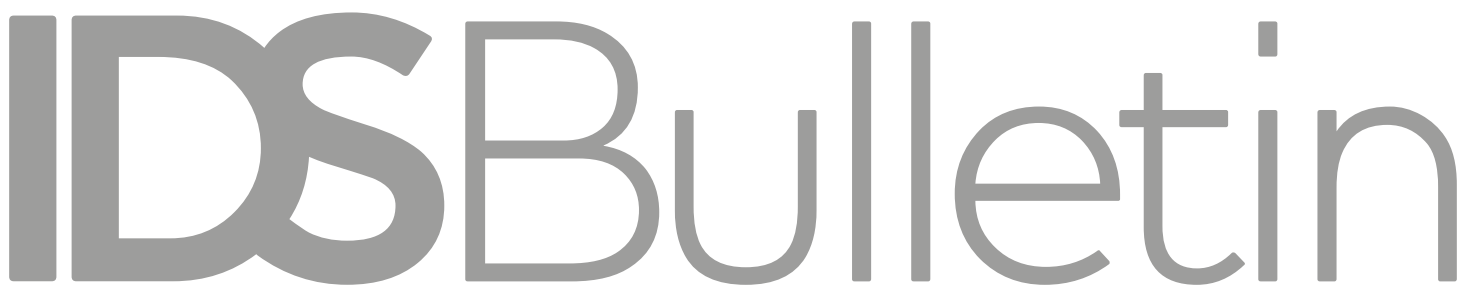

Transforming

Development Knouledge

Volume 50 | Number 1 | May 2019

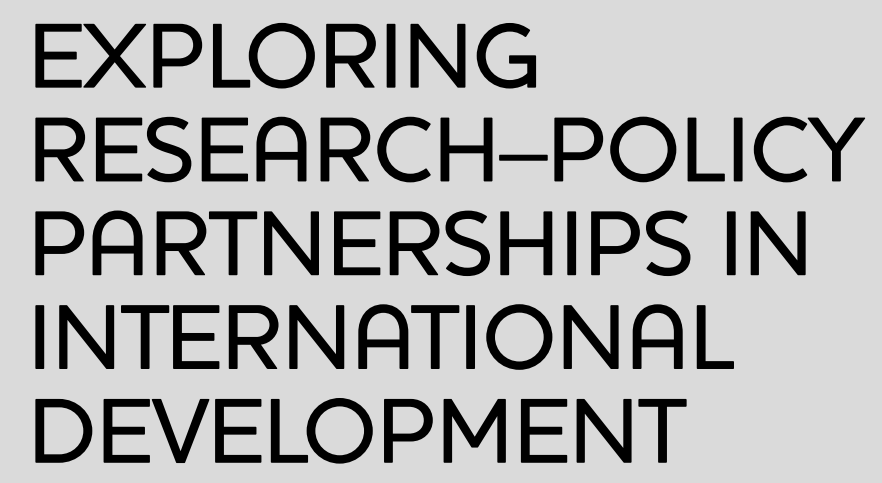

Editors James Georgalakis and Pauline Rose

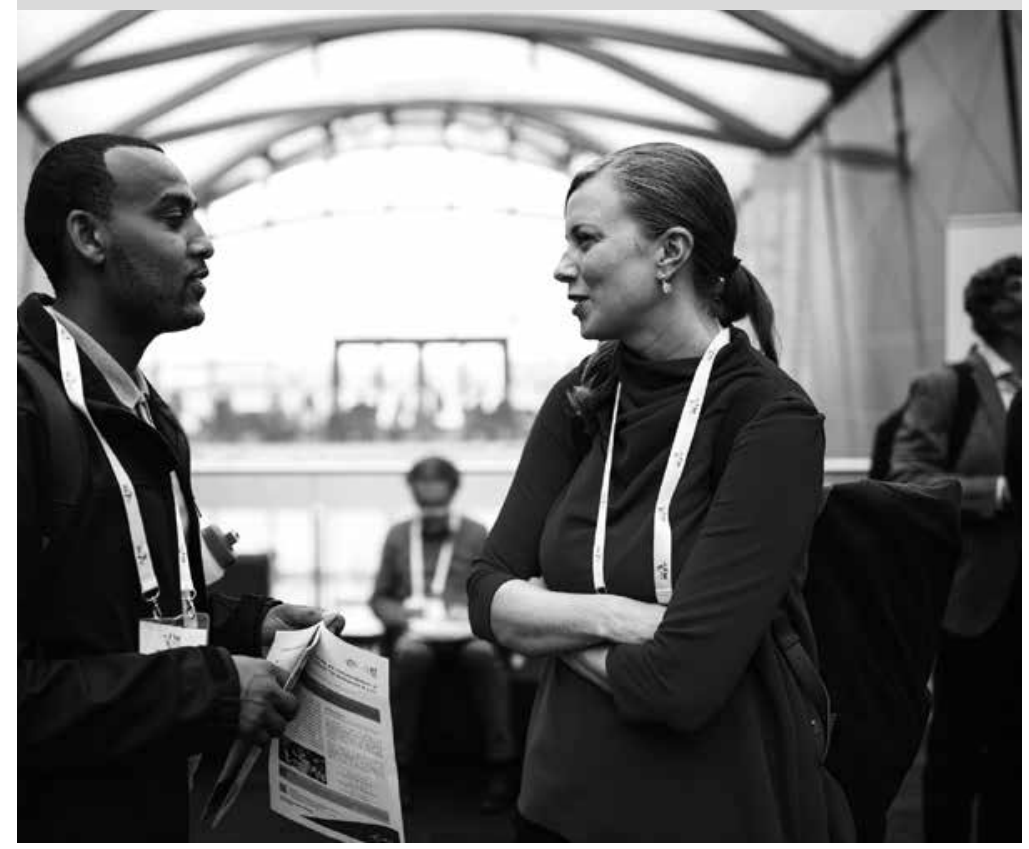


Notes on Contributors

Foreword

Diana Dalton

Introduction: Identifying the Qualities of Research-Policy Partnerships in International Development - A New Analytical Framework

James Georgalakis and Pauline Rose

Rethinking Research Impact through Principles for Fair and Equitable Partnerships Kate Newman, Sowmyaa Bharadwaj and Jude Fransman

Pathways to Impact: Insights from Research Partnerships in Uganda and India Rachel Hinton, Rona Bronwin and Laura Savage

Exploring Partnerships between Academia and Disabled Persons' Organisations: Lessons Learned from Collaborative Research in Africa

Maria Kett, Mark T. Carew, John-Bosco Asiimwe, Richard Bwalya, Anderson Gitonga, Boakai A. Nyehn, Joyce Olenja, Leslie Swartz and Nora Groce

Layered and Linking Research Partnerships: Learning from YOUR Uorld Research in Ethiopia and Nepal

Vicky Johnson, Anannia Admassu, Andrew Church, Jill Healey and Sujeeta Mathema

\section{Fundamental Challenges in Academic-Government Partnership in Conflict Research in the Pastoral Lowlands of Ethiopia}

Mercy Fekadu Mulugeta, Fana Gebresenbet, Yonas Tariku and Ekal Nettir

Regional Research-Policy Partnerships for Health Equity and Inclusive Development: Reflections on Opportunities and Challenges from a Southern African Perspective

Nicola Yeates, Themba Moeti and Mubita Luwabelwa

How Did Research Partnerships Contribute to Bangladesh's Progress in Improving Lives?

Mushtaque Chowdhury

Glossary 


\title{
Fundamental Challenges in Academic-Government Partnership in Conflict Research in the Pastoral Lowlands of Ethiopia"+
}

\author{
Mercy Fekadu Mulugeta, ${ }^{1}$ Fana Gebresenbet, ${ }^{2}$ \\ Yonas Tariku ${ }^{3}$ and Ekal Nettir ${ }^{4}$
}

\begin{abstract}
The Ethiopian government continuously calls for policy-relevant research. However, this admission of policy challenges and attempts to fill the gap cannot ignore the political economy and power dynamics in Ethiopia. This article discusses challenges to an impactful partnership with government, drawing from the experiences of the 'conflict working group', the ESRC-DFID-funded project 'Shifting In/equality Dynamics in Ethiopia: from Research to Application' (SIDERA). We argue that research should empower communities; however, to government, research is a tool to buttress efforts to 'secure' and 'pacify' the lowlands to eventually facilitate extraction. The article also addresses the lack of consensus on basic concepts such as conflict. We argue that it is a rational response to environmental change and state-led dispossessions, while to government, it is an expression of 'backwardness' and 'irrationality'. The development of a meaningful partnership in this context was dependent on navigating meanings and power relations.
\end{abstract}

Keywords: research partnership, policy impact, conflict research, pastoral conflict, South Omo Zone, Ethiopia.

\section{Introduction}

The discourse and promotion of evidence-based development policymaking has become more entrenched since the 1990s (Pawson 2006; Georgalakis et al. 2017; Nelson 2017). Evidence generated from university research is more trusted than other sources, although the former is less read (Shucksmith 2016), and the desired engagement with policy and decision-making is often opportunistic and mainly used to re-confirm existing policy ideas (Newman et al. 2013). Changes in research funding schemes - which puts emphasis on the 'elusive "impact" - push researchers towards collaborating and partnering with practitioners. Similarly, practitioners are pushed towards researchers 
in search of reliable and trusted sources of knowledge to inform the decisions they make. Despite this, policymakers have an occasional interest in 'buying' new ideas and are more open in times of crisis or reform (Green 2017).

Moreover, despite this emerging interdependence, the struggle of policymakers engaged in research to maintain their autonomy and the other researchers to get heard leads to the continued presence of an 'impermeable barrier' between researchers and policymakers (Sen et al. 2017). This research-to-policy gap is increasingly being bridged through the co-production of knowledge in processes of action research, and of building trust and channels of consistent communication (Georgalakis et al. 2017). It should be emphasised here that 'research to policy processes are largely social. Technical capacities matter... but not nearly as much as the social factors' (ibid.: 17). The way to handle the 'social matters' and 'turn research into action' is by 'strengthening relationships between researchers and local government officials', differently put as investing in the building of networks and partnerships (Georgalakis 2016).

This, however, is not a straightforward process. In the first place, context matters a lot and the individual relations between representatives of the different stakeholder institutions have a pivotal role in determining the success of the partnership/impact (Wessells et al. 2017). This will become crucially visible in cases of research on sensitive topics which need careful navigation of domestic and/or local politics (ibid.). Wessells et al. (2017: 91) go to the extent of concluding that 'researchers who want to have a significant impact on policy should identify and cultivate a positive relationship with a well-positioned person who can serve as both a power broker and a trusted adviser.' This, however, invites informality and reduces the institutionalisation of changes and the sustainability of impacts. Secondly, creating networks and building partnerships is not a technical process; rather, it is a process fraught with questions of power. This has been recognised for a long time in the literature, especially in cases of partnerships between donors from the North and implementing non-governmental organisations (NGOs) in the global South (Crawford 2003; Harrison 2002; Lister 2000). This makes the task of building trust and participation in decision-making crucial components of partnering - trickier.

Based on a unique case of South-South within-country partnershipbuilding efforts, this article argues that the challenges inherent to North-South partnership are replicated in South-South partnerships. These 'impermeable barriers' (Sen et al. 2017) are related to the very aims that research should achieve, the divergent conceptions and views on the local community, and constraints emanating from contested power relations between the partnering institutions. These challenges are manifested despite the possession of an insider perspective on contexts and dynamics by the research team. The uniqueness of the case is from two perspectives. First, most of the available literature on partnerships and impact focus on collaborations between institutions 
based in the global North with those in the global South. Questions of the discourse of partnerships concealing power relations across the global North-South divide abound. Thus, our contribution looks into similar dynamics within South-South partnership dynamics, within a similar broader cultural context. Second, the available literature focuses on partnerships over 'soft' issue areas, such as health, participatory environmental conservation, and child protection (social issues) (Boaz, Baeza and Fraser 2011; Murthy et al. 2012; Oliver et al. 2014). This article discusses a case of conflict research, a more sensitive issue on which governments tend to be less willing to partner (particularly so in Ethiopia, as will be shown in the next section).

We are basing our argument on the long-term engagements of the first two authors in South Omo Zone, Southern Nations, Nationalities, and Peoples' (SNNP) regional state of Ethiopia (see Mercy 2016, 2017; Asnake and Fana 2012, 2014; Tewolde and Fana 2014). This more informal engagement was further crystallised by becoming part of the Omo-Turkana Research Network, ${ }^{5}$ which culminated in an ESRC-DFID-funded research 'Shifting In/equality Dynamics in Ethiopia: from Research to Application' (SIDERA). ${ }^{6}$ This research project created the platform for researchers based in Addis Ababa University at the Institute for Peace and Security Studies (IPSS) (Mercy Fekadu Mulugeta, Fana Gebresenbet, and Yonas Tariku) to partner with researchers based in the UK and US. The latter are responsible for two working groups of the project: environmental sustainability/resource dynamics and wealth/poverty dynamics. This article is more focused on a third working group, the Conflict Working Group (CWG), which was implemented exclusively (without reducing the importance of crossfertilisation across working groups) by the team from IPSS.

The CWG is tasked with mapping new inter-group violent conflicts that have emerged in South Omo and identifying key issues in the conflict. It also investigates how changing resource access has affected conflict dynamics and how the interplay between environmental sustainability, inequality, and conflict is affecting socioecological resilience at the scale of communities and at the level of the Omo Basin. In addition to activities related to the CWG, the IPSS team also took the lead in facilitating access and good offices of relevant government officials for the other two working groups (starting from December 2017). As such, the SIDERA activities created the platform for a better institutionalisation and formalisation of the working relations between the IPSS and government, federal, regional, and zonal. In addition to the procedural issues, selected government officials are involved in the different stakeholder mapping and other processes (in Addis Ababa (federal, regional, and zonal government officials) in February 2017; in Jinka and Kangaten (zonal and district government officials) in July and August 2018), and are planned to be included in the synthesis workshop in May 2019. As such, the plan was to create a strong partnership over the course of the project's lifetime. 
Despite the desire of higher officials to involve academics in the development of policy tools and knowledge (Ethiopian Broadcasting Corporation 2018), several challenges hinder effective cooperation between academics and policymakers in Ethiopia. This article attempts to better understand these fundamental challenges impeding the application of knowledge produced by academics in policymaking. The key question to be answered is: What are the challenges of academics-government research partnership on development and conflict resolution in South Omo Zone? These challenges emerge as academics try to inform government perspectives with evidence on pastoralist reactions, aiming to contribute towards a more appropriate government response in conflict prevention and management. This article is a qualitative analysis based on interviews of key government officials, analysis of government annual reports, and a critical assessment of the experiences of the CWG (including before the project life of SIDERA).

The SIDERA/CWG sees research as empowering, and has therefore adopted qualitative interpretative methodology. Contrary to traditional views, rooted in positivist quantitative approaches, on research as an impartial endeavour, quantitative as well as qualitative research can be empowering to communities and its audience (Canessa 2006). For both moral and scientific reasons, the CWG/SIDERA researchers openly advocated for the selection of a community-relevant research agenda and the voicing of local voices in the process (Herbert 1996; Schwarzer, Bloom and Shono 2006). This philosophy has shaped both the research process and the development of this article.

The remainder of this article is structured in three parts. Section 2 gives the national and local context within which the SIDERA/CWG project was implemented. Section 3 presents three barriers to forging a strong/ impactful partnership. The first dwells on the differing definitions and conceptualisations of what research is and should achieve. The second highlights the incongruent views of researchers and government actors towards the local community and the rationality of its acts, specifically in conflict. The third presents moments of clashes/contestations of differing forms of power possessed by researchers and government officials. Section 4 concludes the article.

\section{SIDERA/CWG in the partnership landscape of Ethiopia}

The South Omo Zone is located in southwestern Ethiopia and is home to 16 pastoralists and agro-pastoralist ethnic groups. Ethiopia has been a federal state since 1993 and is divided into nine regional states. South Omo is one of the zones in the Southern Nations Nationalities and People's Region of Ethiopia. Before it became a federal state, Ethiopia was a feudal state (late nineteenth century to 1974) and a socialist state (1974-91). Feudalism has been a major socio-political feature of large parts of the country, even before the creation of the modern Ethiopian state in the late nineteenth century (Clapham 2002). The political capital, Addis Ababa, of the last feudal emperor, continues to be the capital of present-day Ethiopia. 
Despite the practice of federalism in Ethiopia, the importance of a strong centre is crucial in explaining the nature of governance and the policymaking landscape. The former centre, Addis Ababa, is also the current centre, where both political and economic power is concentrated. The South Omo, one of the last additions to the federal state, continues to be the political, geographic, and economic margins of the country (Yntiso 2012). The type of governance practised by the dominant party coalition, the Ethiopian People's Revolutionary Democratic Front (EPRDF) centralises decision-making in the political capital in a way that the decision-making power of the regional states and local governments is retracted.

The policies of the EPRDF are tuned by the developmental state model whereby poverty is defined as the main national challenge, and economic development is the remedy. This is done through centralised and often oppressing methods that are implemented at the cost of regional autonomy and individual liberty. The 2009 Charities and Societies proclamation, and 2008 Freedom of the Mass Media and Access to Information proclamation effectively curtailed any debate on rights-related policy issues. As such, conflict management is in the hands of government institutions and to some extent traditional practices often argued to be co-opted by the government.

The SIDERA project itself is aimed at contributing towards positive change by bringing about a shift in perspective that would be reflected in changes in narrative, to be expressed both in policy and discourses. State-led development initiatives are transforming the zone into a hub of sugar production and export, aimed to increase national sugar production from 17 million to 42 million tonnes, at social, cultural, and environmental costs. Such production will produce an annual income of US $\$ 661.7 \mathrm{~m}$ and alternative energy, 304,000 $\mathrm{m}^{3}$ of ethanol per year, and 607MW electricity (Tewolde and Fana 2014). Close to half of the new sugar production at national level is expected to be sourced from the 125,000 hectares allocated for sugarcane plantation and industry in South Omo. According to the federal government, this land is 'underutilised' by the inhabitants of South Omo who practice pastoralism as a mode of livelihood (Eyasu 2008; this view is also confirmed by various interviews at the Ethiopian Sugar Corporation).

The South Omo Zone, while geographically located in the SNNP region, is usually listed along with what the federal government calls emerging regions (Afar, Somali, Gambella, and Benshangul-Gumuz), which are known to be 'lag[ing] behind the rest of the country' due to marginalisation, and which have several 'harm-inducing customs' (FDRE Government Communication Affairs Office 2015). These 'emerging regions' are predominantly lowland areas, and are conceptualised as 'the last frontiers' (Markakis 2011). These constitute territories yet to be fully mastered by the Ethiopian state. 
We conceptualised the SIDERA project with the expectation that research and research-based evidence that cultivates the right partners and modes of partnerships feeds policymaking and benefits target communities by bringing their voices into policymaking platforms far from where they could otherwise reach. The partnership stands to benefit about 300,000 people living in the South Omo Zone. Most of these potential beneficiaries are poor and marginalised pastoralist communities whose livelihoods and social dynamics have been greatly negatively affected by the development projects, i.e. sugar plantation/ industrialisation and villagisation.

This article addresses challenges that lie beyond the most cited academic-non-academic partnerships in the literature, including barriers related to physical and bureaucratic distance, cultural difference, and lack of time and funding (Nelson 2017). In other words, it addresses what lies ahead once academic and non-academic groups are in touch, having found the interest, time, and funding and, relatively speaking, are within the same cultural and political context. Setting aside the bureaucracy that lies between any government official and citizen, there is relatively little or no physical barrier between the research team and non-academic partners at the regional and federal government. The CWG research team is based in Addis Ababa, the capital city of Ethiopia, where the partner at the federal government level, i.e. the Ministry of Federal and Pastoral Development Affairs is based. Policymakers at the regional (sub-national) and local level also travel to the capital city frequently. In addition, the research team has an institutional partner, the South Omo Research Centre, through which it can make contact with the zonal and wored $a^{7}$ (hereafter, district) governments. The data collection journeys also facilitated face-to-face contact. Moreover, the informal networks of the first two authors since the early 2010 s smoothed relations.

In terms of language, the working language of all three levels of governments, Amharic, is also the mother tongue of all three research team members. However, it is only a small section of the Nyàngatom, i.e. the local community at district level - who have done some years of schooling (and invariably work for the government) that could speak in Amharic. Furthermore, the difference in research and policy language is apparent between government and academics. While all partners are based in the same country, their priorities and culture of knowledge production, vocabulary, and objectives created some challenges.

SIDERA/CWG aimed to forge partnerships with non-academic institutions at the federal, regional, and zonal levels in Ethiopia. This process was unique due to (1) the country's political landscape, (2) the nature of public institutions, and (3) the centre-periphery dynamics. Besides these features, to be discussed in detail below, some key contextual issues make analysis on this particular process unique from the literature on partnership and policymaking. 
The first contextual factor is Ethiopia's political landscape. The policymaking sphere is dominated by governmental actors and is restricting to research institutions and civil societies working especially in the fields of conflict and peace research. Dissent is rarely tolerated in Ethiopia's political culture, and the country's political order has been dominated by the EPRDF since 1991 and several restrictive laws since 2009. The challenge of conducting emancipatory research in such a hostile context while maintaining the necessary objective distance from government influences is clearly big.

The second contextual factor relates to public universities in Ethiopia. There is a dramatic increase in higher education institutions and intake. This, however, is not matched by research and publication outputs, due to a drop in the quality of education, high brain drain, and inefficient use of resources (Teshome 2005). Like most public sectors in the country, besides meeting the growing demand for higher education, the increase in the number of such educational institutions has been attuned to producing the required manpower to meet national 'developmental' goals. These goals are specified in the national fiveyear plans, Growth and Transformation Plans I and II, among others, and have been met by disproportionately investing in the natural and computational sciences. Higher education institutions are expected to directly contribute towards government-led development initiatives throughout the country, rather than critiquing it.

The third contextual factor is the historically established relations between a powerful centre and a weaker periphery, especially the pastoral frontier. Unlike other federal states, Ethiopia's practice of federalism, so far, lacks the quality of decentralisation and power balance expected between federal and regional institutions. What the constitution decentralised is centralised through the ruling party (Belay 2012). In practice, this dynamic is characterised by Ethiopia's centreperiphery relations, within which the federal institutions, based at the geographic and political centre, Addis Ababa, define and control the peripheries. The relation between a powerful centre that actively subjugates and exploits is more expressed in places such as the South Omo Zone. This is due to the geographic distance from the centre, the small numerical size of the ethnic groups, and the dominance of pastoralism as a mode of production (see Markakis 2011).

Public institutions need official channels that facilitate access to data, and form research and data-sharing partnerships with governmental institutions. This process involves fulfilling certain institutional formalities, such as formal written communications from department heads but with no binding framework agreement or the signing of formal agreements, such as MoUs. Once started, the process builds on informal structures and communications which would be impossible without the formality.

After winning the ESRG-DFID grant, the IPSS initiated formal communication with the relevant government offices aiming to ensure 
Figure 1 The 'FIT Model': partnership as an iterative and dynamic process

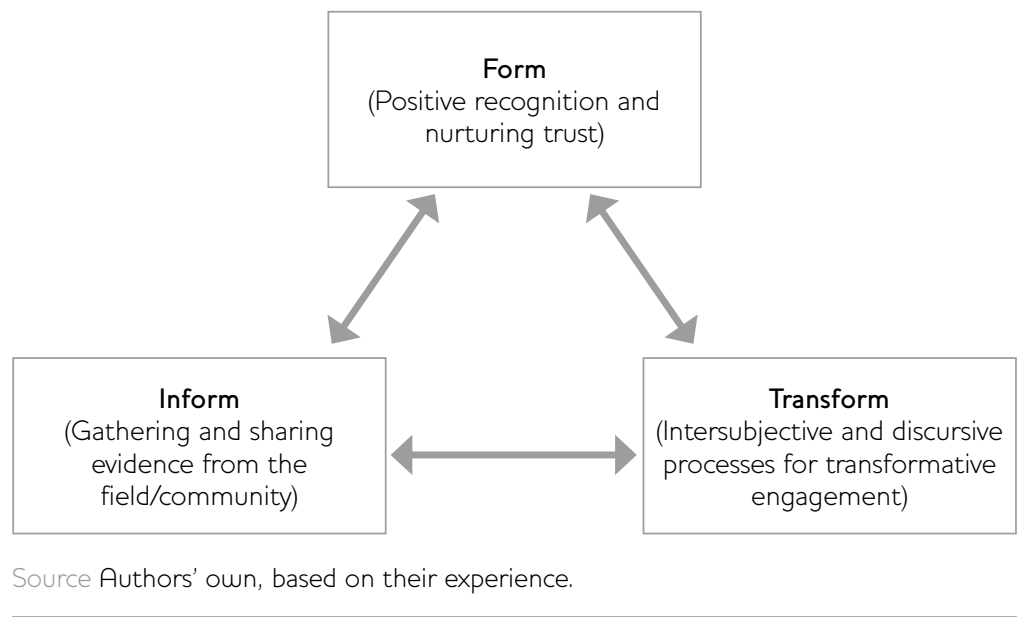

the smooth running of the fieldwork, meaningful engagement of policymakers at all levels of the research, and to ensure policy uptake at a later stage. However, a binding agreement was not developed or signed. The letter, written by the IPSS, introduced the project and invited government institutions - such as the Ministry of Federal and Pastoral Development Affairs, the SNNPR's Pastoralist Affairs Bureau, and the Zonal Administration Office - for planning and launch, and facilitated continuous engagement. The IPSS also sent formal letters to the district government at the very local level. Such formality is possible because the IPSS is part of a public higher institution, Addis Ababa University, which is mandated to conduct problem-solving research and provide evidence to policymaking institutions. ${ }^{8}$ The initial working relationship of the first two authors meant that this was primarily a formalisation of an existing relation, reducing frictions at the very start of the project. Besides being involved at the planning level and the sharing of data, at a later stage these governmental organisations will be part of a synthesis and findings presentation workshop.

\section{Challenges of government-academia partnership \\ 3.1 Contradictions on the objectives of research}

Ideally, and as set out in the context of SIDERA, the CWG research process incorporated three major components having a triangular flow, which we call the 'FIT Model' (see Figure 1). The first component is gathering evidence from the field/community which then contributes to informing our stakeholders' (at the district, zonal, regional, and national levels) decisions related to the perspectives of the pastoralists. The second component builds on the first one - through iteration - and aims at forming or consolidating networks and non-formal partnerships by mutual recognition and nurturing trust. Finally, the third component would be a product of the other two in which the evidence-mediated intersubjective and discursive processes result in transformative engagements between the academic and non-academic partners. 
The process is not linear and unidirectional as presented above, however. At the heart of this iterative process is that the research does not just end at the point of uncovering, analysing, and filling the knowledge gap. Rather, it goes beyond that and serves as a conduit through which local voices are reverberated and heeded, and decision makers' perspectives are accordingly shaped or influenced. Therefore, it is through this process of informing (via empirical evidence), forming (networks and partnerships as a result of recognition and trust), and transforming (through intersubjective and discursive processes) that the CWG sought to generate impact. ${ }^{9}$ Also, it is, in the main, this engagement that would empower, if not emancipate, pastoralist communities.

In reality, however, the divergent view of academics and policymakers, in regard to what research ought to achieve, happens to be quite a challenge. To the academics informed by the Critical Research Paradigm, research should produce empirically grounded knowledge which empowers communities; while, to the Ethiopian government, research is a tool to buttress efforts to 'secure' lowlands and facilitate extraction by confirming the government's fundamental assumptions. Obviously, these views are on a collision course as they seek to achieve different outcomes vis-à-vis the existing structures of relations between the pastoralist communities and the government or its functionaries who are busy with the ongoing 'development' interventions in the area. Put differently, the researchers' efforts to bring the pastoralists' voices to the fore and the policymakers' firm interest to 'extract' from and control the latter end up in a head-on confrontation.

To try to bridge this gap in the 'what' and 'why' of research is indeed a trying enterprise for the apparent reason that policymakers often operate on what they have decided are national priorities, rather than on the researchers' fanciful ideas of empowerment and emancipation, which, according to the view of government officials, lack any practical relevance. This should not be construed to mean that policymakers are completely oblivious to the plight of pastoralist communities; rather that the state-led 'developmental' policies (see Fana 2015) are the remedy. Thus, it is the government who should be heard by the pastoralist community, not the other way around. And, it is here where, from the policymakers' perspective, research ought to prove its relevance as a tool to realise national policy priorities. In this case, therefore, the most common challenge is the 'conflict between research recommendations and policymakers' priorities' (Greengrass 2017: 24). This is how 'the ideology of government ministers (i.e. if fixed) may prevent engagement even where empirical evidence supports a policy change and this can hamper research findings from contributing to instrumental impact through change of policy or practice' (ibid.: 24).

It is under these circumstances that the degree of politicisation and subsequent securitisation of an issue can easily entangle issues in unsolicited political interpretations. Empirical evidence suggesting that 
such complications are most common in the social sciences than in the hard sciences is lacking; however, politicisation and securitisation of issues is easier to warrant in the social sciences (Balzacq 2005). Since, compared to policymakers, the researchers have literally no power to depoliticise and/or desecuritise an issue, they have to rely on promoting positive recognition and nurturing trust which requires ample time and intersubjective understanding. This, in turn, will be built on the long-term contacts and non-formal networks the researchers and IPSS have established with officials and experts who are in charge of Pastoralist Affairs and Security and Administration desks at various levels and branches of the government. As the supposed end-users of research findings and recommendations, it is through these long-term acquaintances and the non-formal partnership with these individuals and their offices that the research is expected to eventually empower pastoralist communities. At the moment, shifting the perspectives of these government functionaries appears the most plausible path to eventually impacting policies.

\subsection{Contrasting views on pastoralism and pastoralists' responses}

The ministerial bodies at the federal government have identified four major issues as the source of conflict in South Omo Zone: these are the lack of good governance, issues related to land claim, self-determination, and harmful traditional practices such as cattle raiding and payment of bride price. ${ }^{10}$ Of these, cattle raiding is the most frequently mentioned cause of conflict by South Omo officials. ${ }^{11}$ The high number of cattle to be paid as dowry, as high as 40 in some communities, is mentioned as the 'irrational' reason behind these raids, while economic interest, environment, and other development-related wealth dynamics are not mentioned. These practices are labelled 'harm-inducing social practices' rampant in 'backward' regions such as the South Omo Zone and to be addressed by awareness-raising campaigns that supplement government-led development projects (FDRE Government Communications Affairs Office 2015).

To the government, the local community's resentment and resistance of 'development' interventions such as the expansion of farmlands, resettlements, and private investment projects is for no particular reason. The 'irrationality' of such resentments is best presented by the words of the security administration head: 'The Mursi demand appointment of one of their own as managers and payments (as a salary even if they don't work). This demand is not limited to projects but also administrative structures'. ${ }^{12}$ In some parts of the zone, the act of violence targeting vehicles is seen as the ultimate 'irrational' act also. ${ }^{13}$

Solutions proposed by the government naturally address these concerns. For instance, self-determination has been addressed through the restructuring of district administrative territories on the basis of ethnicity; in practice, this move has reframed land claims into administrative entitlements. For example, the Nyàngatom district was founded in 2006 in response to frequent violent incidents with the 
Dasanech, when the two groups were administered jointly under the then Kuraz district. On the other hand, 'development' interventions are expected to solve all other ongoing sources of conflict in South Omo, including good governance, largely defined as the lack of public services, and harmful traditional practices.

Assertions by researchers that conflict is a rational response to state-led dispossessions are completely disregarded. To government, conflict is an expression of 'backwardness' and 'irrationality' to be solved through 'development' and sometimes with the 'necessary' and 'inevitable' punitive security measures. This takes place in the form of regular 'security campaigns' during which suspected individuals, mainly young men, are targeted. In addition to this, the campaigns serve as a display of force and create an atmosphere of fear, which makes communities subservient. The experience in certain areas in the zone such as Salamago shows that government interventions advanced in the name of development and security bred more insecurity. The attempt of scholars to bring this to the fore is at the very least ignored. At the extreme, the government blames foreign researchers for fuelling the conflicts by misguiding the local community (Meles 2011).

A close and systematic analysis of events in pastoralist communities shows that conflict is a rational act of survival closely tied in with physical and livelihood security. Pastoralist conflicts, for instance those frequent between the Nyàngatom, the Dasanech, and the Suri, are a means to gaining livelihood items through cattle raiding or sorghum theft (Mercy 2017; Glowacki and Wrangham 2013). Similarly, territorial conflicts, such as one between the Nyàngatom and the Kara or the Turkana and the Nyàngatom, are a means to the nourishment of these livelihood items as territorial conquest ultimately serves as grazing land for cattle and flood retreat agricultural land to produce sorghum (Greiner 2013; Girke 2008; Tornay 2009). The ambushes and arson in Salamago district is also an expression of resistance to dispossession of land, paternalistic handling of communities, and an attempt to maintain their autonomy (Buffavand 2017).

Pastoralist communities in South Omo have narratives of historical constructions of conflict with neighbouring communities (existential 'enemies') and have lived through perennial conflicts their entire living memory. The situation is further complicated and the security of these communities threatened even more as their territory shrinks due to land-intensive government-led development projects such as sugarcane plantations. Their livelihood and way of life is threatened as well. The 'development' initiatives and the villagisation projects encourage a shift in lifestyle and discourage the pastoral transhumant method, calling it 'a life of one that follows the tail of a cow'. Pastoralism is taken as anachronistic, a thing of the past and unproductive. Flood retreat agriculture, though not discouraged like pastoral cattle herding, is currently impossible due to the tremendous decrease of floods after the construction of the Gibe III dam (Kamski 2016). Within this context, 
pastoralist conflict has become a deliberate act of resistance and survival that stands in the face of dispossesive development projects.

Such difference between government and academia on the definition of pastoral conflict is not merely a 'semantic acrobatics' but a conceptual contradiction at the heart of a nation's political economy. For this reason, the main impact objective envisaged through this partnership is a conceptual shift that is slowly but surely progressing through years of engagement of researchers (not just SIDERA but others as well) with government officials. As one former district government official ascertained, 'I used to see revenge as the sole reason for pastoralist conflicts... I now understand [through interaction with researchers] that the main reason for pastoralist conflict is economic.' Governmentacademic partnerships should help bring such change in perspective, noting that the culture of raiding, dowry ambushes, arson, and other supposedly 'irrational' practices are in fact ways to economic security and access.

\subsection{Power contestation}

The SIDERA partnership was an iterative process in a field of power. The partnering process was conditioned by the balance and negotiation of differing forms of power. The academic partners possess 'soft powers' of producing evidence-based knowledge and articulating it within broader national/local economic and historical processes. Non-academic partners on the other hand have 'hard powers' related to bureaucratic red tape, power over the accessibility of state records and archives, and the potential limitation of where the researcher could go and who she could talk to. Government officials, as non-academic partners, are crucial to the actual implementation of the research and the quality of data generated.

This occurred with the South Omo Research Center (SORC) in late 2012 and early 2013, at the start of the sugar industrialisation and villagisation activities, amidst increasing resistance by the local communities and the ensuing tension. The government did not properly consult the local communities (Yidnekacew 2015), and blamed the failure to get the allegiance of the pastoralists on the SORC and the researchers (mainly foreign anthropologists) operating there. This, inter alia, led to the deportation of the SORC's Director and the closing of the SORC temporarily.

Therefore, the earliest work of the CWG team members was mainly based on informal networks and with low-key engagement with the SORC and researchers affiliated to it. In due course, after gaining the trust of the zonal administration and partnering with the new leadership of the SORC, now based at Arba Minch University, the team was able to more easily work directly with the zone government and communities. Members of the CWG now face practically no significant barriers from the zone government to conduct researches there, even in collaboration with individuals the government suspects 
of being 'anti-development' and feeding the 'wrong' stories to international organisations, such as the Oakland Institute and Human Rights Watch. ${ }^{14}$

Not all power dynamics are resolved amicably though. For example, in late 2012, at the peak of intense international criticism (see Human Rights Watch 2012) of the Ethiopian government for alleged human rights violations in the name of promoting land investments, the IPSS initiated a research project which looked into the socio-political and conflict implications of such investments (see findings in Mulugeta 2014). The primary national actors in this process were the Agricultural Investment Support Directorate (AISD) within the Ministry of Agriculture and the Ethiopian Sugar Corporation. The AISD at the time insisted that they become stakeholders in the research, and that the IPSS and AISD sign an MoU. The IPSS did not welcome this, fearing encroachment into the freedoms of researchers, and this initial friction led to a difficult start. Both actors viewed the other suspiciously, and without steps being taken to resolve this mistrust, that project ended up with a limited working relationship.

Similarly, our working relationship is much more advanced and trust-based at lower government levels, in zone and district, than at higher levels. Power relations become more limiting as one goes up, to regional or federal levels of government. To get the attention of government officials and to build a genuine partnership at these levels, a much higher scope of funding and activities are needed - be it in funds generated, geographic areas concerned, and time period for the research. These senior government officials appear to be more interested in more general and high-impact issues. Considering the limited scope of our funds and work experience therefore, the rational thing to do was to mainly focus at lower levels of government.

This, however, also comes with a cost to potential impact. The characteristic centre-periphery relations in Ethiopia, further buttressed by the logic of developmentalism, essentially means that resources could be extracted from the peripheries with little consideration of the costs there (Fana 2015; Markakis 2011). Moreover, the state aims to expand its power and hegemony to the pastoral lowlands through these 'development' schemes (Fana 2016; Lavers 2016; Lavers and Boamah 2016). As such, policy decisions are made in the centre with little consideration other than promotion of rapid development and security (see also Mercy 2016), while the lower government officials implement whatever comes from the centre with little scope for resistance and adaptation to local realities (Markakis 2011). As such, partnerships with significant impact on policy should involve representatives from higher levels of government. If one partners below, it will at the very best take a long time for the impact to be felt at higher levels of government and induce a change in policy. 


\section{Conclusion}

Government calls on researchers to contribute to national development on various occasions, presuming that 'national priorities' and 'reality' are uncontested, and that researchers will naturally subscribe to the state's conceptualisations. Thus, to government, partnering with academic institutions is like having a branch of government that provides evidence-based knowledge to further the state's defined interests and approaches to deal with a certain socioeconomic/political challenge, not to contest it. A serious and fruitful partnership between academics and policymakers needs to navigate this contradiction in view of reality and the objective of research.

Moreover, the Ethiopian government presents itself as the vanguard of the masses, and as such defines the problem, solution, and the way to do it. In this process, the views and understandings of sections of the population, in this case the pastoralists, can be overlooked. The latter are viewed as 'irrational' 'backward' actors, who do not know and cannot make a rational decision, be it in development or conflict management/resolution. The researcher here is well positioned to articulate the thinking and rationality of the 'underdog' and in the process empower the pastoralists. These two challenges in the partnering process - the final objective of research and view of local community - is further complicated by power dynamics. Academics have 'softer' power in leading the partnering process. Negotiating these power dynamics, although much easier than North-South partnerships, is crucial in building partnerships between Southern actors; even amongst institutions located in the same country.

The partnership process should not be viewed as unilinear or unidirectional. It is, rather, an iterative, dynamic, and evolving process which involves three major forms of interaction which we labelled the 'FIT Model'. One pertains to the generation of data from the field/ community and sharing them with the government with the aim to inform policies and decision-making considerations. This, in other words, relates to addressing the challenge of having a rapport with the government concerning the goal of research (i.e. emancipation and empowerment). Then comes the need to address the challenge of having agreed conceptions and views so as to nurture trust and positive recognition. Positive recognition and trust are thus stepping-stones of forming the partnership with the government.

Once these two forms of interaction are attained, the partnership could take a transformative course and there will be meaningful impact. As a result, building an academic--government partnership is not a onestep act (say signing an MoU and doing a few formal engagements), especially in politically sensitive areas. Partnerships are nourished, (de-)constructed, and (in)formalised in their lifetime. As such, studies on academic ${ }^{-}$government partnerships should adopt a processual and more comprehensive view, rather than aiming to understand a particular moment in the partnership. 


\section{Notes}

* This issue grew out of the Impact Initiative for International

Development Research which seeks to maximise impact and learning from ESRC-DFID's Joint Fund for Poverty Alleviation Research and their Raising Learning Outcomes in Education Systems Research Programme.

+ The authors gratefully acknowledge the funding provided by ESRC-DFID under its Development Frontiers Research Fund Call 2 2016/17 for the research project 'Shifting In/equality Dynamics in Ethiopia: from Research to Application' (SIDERA) ES/R002460/1, from which this article draws its partnership and data.

1 Institute for Peace and Security Studies (IPSS), Addis Ababa University, Ethiopia.

2 Institute for Peace and Security Studies (IPSS), Addis Ababa University, Ethiopia.

3 Institute for Peace and Security Studies (IPSS), Addis Ababa University, Ethiopia.

4 Kuraz Sugar Development Project, Ethiopian Sugar Corporation.

5 For details, visit the Network's website: www.canr.msu.edu/oturn/.

6 www.theimpactinitiative.net/project/shifting-inequality-dynamicsethiopia-research-application-sidera.

7 Woreda is the second lowest administrative unit in the regional government structure, hereafter referred to as district.

8 An individual independent researcher would need to seek affiliation at a public institution; the Institute of Ethiopian Studies at Addis Ababa University provides affiliations for foreign researchers coming to Ethiopia. See Addis Ababa University Vision and Mission, www.aau.edu.et/mission-and-vision/.

9 From the perspective of the Copenhagen School of security studies, intersubjectivity is instrumental in facilitating what aspect or issue of a national policy should be politicised, depoliticised, securitised, or desecuritised (Buzan et al. 1998).

10 Ministry of Federal and Pastoralist Development Affairs, Conflict Early Warning and Early Response Directorate, MoFA Conflict Analysis 2007 EC; Ministry of Federal and Pastoralist Development Affairs, Conflict Prevention and Management Directorate, MoFA Conflict Analysis 2008 EC; Ministry of Federal and Pastoralist Development Affairs, Conflict Early Warning and Sustainable Solutions Implementation Director General, MoFA Conflict Analysis 2009 EG.

11 Security and Administration head of South Omo Zone, interview, August 2018.

12 Security and Administration head of South Omo Zone, interview, August 2018.

13 Injuries and deaths resulting from car accidents in these pastoralist communities have become a source of grievance. Such accidents, now taking the lives of fellow pastoralists, were previously unheard of in these communities and are seen as a violent act from the government, to be settled by an act of revenge. This act of revenge 
might target any vehicle using the road - not necessarily the one that caused a particular accident.

14 Senior Expert, South Omo Zone Security and Administration Bureau, interview, August 2018.

15 The English version of this reference is Ayele, Y. (2015) 'Policies and Practices of Consultation with Pastoralist Communities in Ethiopia: The Case of Omo-Kuraz Sugar Development Project', in Y. Aberra and M. Adbulahi (eds), The Intricate Road to Development: Government Development Strategies in the Pastoral Areas of the Horn of Africa, Addis Ababa: Institute for Peace and Security Studies.

16 The English version of this reference is Berhe, G.M. (ed.) (2014) A Delicate Balance: Land Use, Minority Rights and Social Stability in the Horn of Africa, Addis Ababa: Institute for Peace and Security Studies.

17 The English version of this reference is Elias, E. (2008) Pastoralists in Southern Ethiopia: Dispossession, Access to Resources and Dialogue with Policy Makers, DCG Report 53, Oslo: Drylands Coordination Group.

18 The English version of this reference is Gebre, Y. (2012) Environmental Change, Food Crises and Violence in Dassanech, Southern Ethiopia, Berlin: Freie University.

19 The English version of this reference is Gebresenbet, F. (2016) 'Land Acquisitions, The Politics of Dispossession, and State-Remaking in Gambella, Western Ethiopia', Africa Spectrum 51.1: 5-28.

20 The English version of this reference is Gebresenbet, F. (2015) 'Securitization of Development in Ethiopia: The Discourse and Politics of Development', Review of African Political Economy 41.suppl 1: S64-S74.

21 The English version of this reference is Kefale, A. and Gebresenbet, F. (2014) 'The Expansion of the Sugar Industry in the Southern Pastoral Lowlands', in D. Rahmato, M. Ayenew, A. Kefale and B. Habermann (eds), Reflections on Development in Ethiopia: New Trends, Sustainability and Challenges, Addis Ababa: Forum for Social Studies and FES.

22 The English version of this reference is Kefale, A. and Gebresenbet, F. (2012) 'Discrepancies between Traditional Coping Mechanisms to Climate Change and Government Intervention in South Omo, Ethiopia', in M.G. Berhe and J-B. Butera (eds), Climate Change and Pastoralism: Traditional Coping Mechanisms and Conflict in the Horn of Africa, Addis Ababa: Institute for Peace and Security Studies (IPSS) and University for Peace (UPEACE).

23 The English version of this reference is Mulugeta, M.F. (2017) 'Small Arms and Conflict among East African Pastoralists: The Karamoja (In)Security Complex', Africa 87.4: 739-57.

24 The English version of this reference is Mulugeta, M.F. (2016) 'Statehood, Small Arms and Security Governance in Southwest Ethiopia: The Need for an African-Centred Perspective', in S. Okello and M. Gebremichael (eds), African-Centred Solutions: Building Peace and Security in Africa, Addis Ababa: Institute for Peace and Security Studies.

25 The English version of this reference is Woldemariam, T. and Gebresenbet, F. (2014) 'Socio-Political and Conflict Implications of 
Sugar Development in Salamago Wereda, Ethiopia', in M.G. Berhe (ed.), A Delicate Balance: Land Use, Minority Rights and Social Stability in the Horn of Africa, Addis Ababa: Institute for Peace and Security Studies. 26 The English version of this reference is Yigenzaw, T. (2005)

'Policy Development in Higher Education in Ethiopia and the Role of Donors and Development Partners', paper presented at the international expert meeting 'Formulas that Work: Making Higher Education Support More Effective', The Netherlands, 23-24 May, https://pdfs.semanticscholar. org/9cc5/263bbdd32d44aacf7d0d243af61c9362c15a.pdf (accessed 25 October 2018).

27 The English version of this reference is Zenawi, M. (2011) Speech during the 13th Annual Pastoralists' Day Celebrations, Jinka, South Omo, 25 January, www.mursi.org/pdf/Meles\%20Jinka\%20speech.pdf (accessed 14 March 2019).

\section{References}

Yidnekacew Ayele (2015) 'Policies and Practices of Consultation with Pastoralist Communities in Ethiopia: The Case of Omo-Kuraz Sugar Development Project', in Y. Aberra and M. Adbulahi (eds), The Intricate Road to Development: Government Development Strategies in the Pastoral Areas of the Horn of Africa, Addis Ababa: Institute for Peace and Security Studies ${ }^{15}$

Balzacq, T. (2005) 'The Three Faces of Securitization: Political Agency, Audience and Context', European fournal of International Relations 11.2: $171-201$

Belay, N. (2012) 'The Nexus between Federalism, Revolutionary Democracy and Decentralisation in the Ethiopian Federation', paper submitted to the 23rd session of the Summer University Program, Fribourg Institute of Federalism, Switzerland

Mulugeta Gebrehiwot Berhe (ed.) (2014) A Delicate Balance: Land Use, Minority Rights and Social Stability in the Horn of Africa, Addis Ababa: Institute for Peace and Security Studies ${ }^{16}$

Boaz, A.; Baeza, J. and Fraser, A. (2011) 'Effective Implementation of Research into Practice: An Overview of Systematic Reviews of the Health Literature', BMC Research Notes 4.1: 212

Buffavand, L. (2017) 'Vanishing Stones and the Hovering Giraffe: Identity, Land and the Divine in Mela, South-West Ethiopia', doctoral dissertation, Max Plank Institute for Social Anthropology, Martin-Luther-Universität Halle-Wittenberg

Buzan, B.; Wæver, O.; Wæver, O. and De Wilde, J. (1998) Security: A New Framework for Analysis, Boulder CO: Lynne Rienner Publishers

Canessa, L. (2006) 'Foreign Language Anxiety: A Close Look at Nonnative Foreign Language Teachers', by D. Schwarzer, M. Bloom and S. Shono (eds), Research as a Tool for Empowerment: Theory Informing Practice, Greenwich CT: Information Age Publishing

Clapham, C. (2002) 'Controlling Space in Ethiopia', in W. James, D. Donham, E. Kurimoto and A. Triulzi (eds), Remapping Ethiopia: Socialism \& After, Oxford: James Currey 
Crawford, G. (2003) 'Partnership or Power? Deconstructing the "Partnership for Governance Reform" in Indonesia', Third World Quarterly 24.1: 139-59

Eyasu Elias (2008) Pastoralists in Southern Ethiopia: Dispossession, Access to Resources and Dialogue with Policy Makers, DGG Report 53, Oslo: Drylands Coordination Group ${ }^{17}$

Ethiopian Broadcasting Corporation (2018) 'Government Vows to Improve Education Quality', 23 July, www.ebc.et/web/news-en/-/governmentvows-to-improve-education-quality (accessed 14 March 2019)

FDRE Government Communication Affairs Office (2015) The Ethiopian Human Rights Landscape in the Context of Right-Based Approach to Development, Addis Ababa: FDRE Government Communication Affairs Office

Yntiso Gebre (2012) Environmental Change, Food Crises and Violence in Dassanech, Southern Ethiopia, Berlin: Freie University ${ }^{18}$

Fana Gebresenbet (2016) 'Land Acquisitions, The Politics of Dispossession, and State-Remaking in Gambella, Western Ethiopia', Africa Spectrum 51.1: 5-28 ${ }^{19}$

Fana Gebresenbet (2015) 'Securitization of Development in Ethiopia: The Discourse and Politics of Development', Review of African Political Economy 41.suppl 1: S64-S7420

Georgalakis, J. (2016) 'Networks of Academics Help Turn Research into Action', The Guardian, 5 April, www.theguardian.com/globaldevelopment-professionals-network/2016/apr/05/networks-ofacademics-help-turn-research-into-action (accessed 5 November 2018)

Georgalakis, J.; Jessani, N.; Oronje, R. and Ramalingam, B. (eds) (2017) The Social Realities of Knowledge for Development: Sharing Lessons of Improving Development Processes with Evidence, Brighton: IDS/Impact Initiative

Girke, F. (2008) 'The Kara-Nyàngatom War of 2006-2007: Dynamics of Escalating Violence in the Tribal Zone', in E.M. Bruchhaus and M.M. Sommer (eds), Hot Spot Horn of Africa Revisited: Approaches to Make Sense of Conflict, Berlin: LIT Verlag

Glowacki, L. and Wrangham, R.W. (2013) 'The Role of Rewards in Motivating Participation in Simple Warfare', Human Nature 24.4: 444-60

Green, D. (2017) 'The NGO-Academia Interface: Realising the Shared Potential', in J. Georgalakis, N. Jessani, R. Oronje and B. Ramalingam (eds), The Social Realities of Knowledge for Development: Sharing Lessons of Improving Development Processes with Evidence, Brighton: IDS/Impact Initiative

Greengrass, E. (2017) 'Designing Programmes to Maximise Mutual Learning', in H. Corbett, E. Greengrass, S. Nelson, A. Stanley and T. Zussman (eds), Overcoming Common Barriers to Research Impact: Five Learning Guides that Explore How Research Can Bring about Change, Brighton: IDS/Impact Initiative

Greiner, C. (2013) 'Guns, Land, and Votes: Cattle Rustling and the Politics of Boundary (Re)Making in Northern Kenya', African Affairs 112.447: 216-37 
Harrison, E. (2002) " "The Problem with the Locals": Partnership and Participation in Ethiopia', Development and Change 33.4: 587-610

Herbert, C.P. (1996) 'Community-Based Research as a Tool for Empowerment: The Haida Gwaii Diabetes Project Example', Canadian Journal of Public Health [Revue canadienne de sante publique] 87.2: 109-12

Human Rights Watch (2012) "What Will Happen if Hunger Comes?": Abuses Against the Indigenous Peoples of Ethiopia's Lower Omo Valley, New York NY: Human Rights Watch, www.hrw.org/sites/default/files/ reports/ethiopia0612webwcover.pdf (accessed 22 March 2019)

Kamski, B. (2016) 'The Kuraz Sugar Development Project', OTuRN Briefing Note 1, www.canr.msu.edu/oturn/OTuRN_Briefing_Note_1.pdf (accessed 21 February 2019)

Asnake Kefale and Fana Gebresenbet (2014) 'The Expansion of the Sugar Industry in the Southern Pastoral Lowlands', in D. Rahmato, M. Ayenew, A. Kefale and B. Habermann (eds), Reflections on Development in Ethiopia: New Trends, Sustainability and Challenges, Addis Ababa: Forum for Social Studies and FES ${ }^{21}$

Asnake Kefale and Fana Gebresenbet (2012) 'Discrepancies between Traditional Coping Mechanisms to Climate Change and Government Intervention in South Omo, Ethiopia', in M.G. Berhe and J-B. Butera (eds), Climate Change and Pastoralism: Traditional Coping Mechanisms and Conflict in the Horn of Africa, Addis Ababa: Institute for Peace and Security Studies (IPSS) and University for Peace (UPEACE) $)^{22}$

Lavers, T. (2016) Social Protection in an Aspiring 'Developmental State': The Political Drivers of Ethiopia's PSNP, ESID Working Paper 73, Manchester: Effective States and Inclusive Development Research Centre, www.effective-states.org/working-paper-73/ (accessed 25 October 2018)

Lavers, T. and Boamah, F. (2016) 'The Impact of Agricultural Investments on State Capacity: A Comparative Analysis of Ethiopia and Ghana', Geoforum 72: 94-103

Lister, S. (2000) 'Power in Partnership? An Analysis of an NGO's Relationships with its Partners', Fournal of International Development 12.2: 227-39

Markakis, J. (2011) Ethiopia: The Last Two Frontiers, Oxford: James Currey Mercy F. Mulugeta (2017) 'Small Arms and Conflict among East African Pastoralists: The Karamoja (In)Security Complex', Africa 87.4: $739-57^{23}$

Mercy F. Mulugeta (2016) 'Statehood, Small Arms and Security Governance in Southwest Ethiopia: The Need for an AfricanCentred Perspective', in S. Okello and M. Gebremichael (eds), African-Centred Solutions: Building Peace and Security in Africa, Addis Ababa: Institute for Peace and Security Studies ${ }^{24}$

Murthy, L. et al. (2012) 'Interventions to Improve the Use of Systematic Reviews in Decision-Making by Health System Managers, Policymakers and Clinicians', Cochrane Database of Systematic Reviewes 2012.9: CD009401, https://doi.org/10.1002/14651858.CD009401.pub2 (accessed 21 February 2019) 
Nelson, S. (2017) 'Opportunities, Ownership and Tailored Outputs: How to Respond to Demand for Evidence', in H. Corbett, E. Greengrass, S. Nelson, A. Stanley and T. Zussman (eds), Overcoming Common Barriers to Research Impact: Five Learning Guides that Explore How Research Can Bring about Change, Brighton: IDS/Impact Initiative

Newman, K. et al. (2013) What is the Evidence on Evidence-Informed Policy Making? Lessons from the International Conference on Evidence-Informed Policy Making, Oxford: International Network for the Availability of Scientific Publications, www.inasp.info/sites/default/files/2018-04/ what_is_the_evidence_on_eipm.pdf (accessed 11 November 2018)

Oliver, K.; Innvar, S.; Lorenc, T.; Woodman, J. and Thomas, J. (2014) 'A Systematic Review of Barriers to and Facilitators of the Use of Evidence by Policymakers', BMC Health Services Research 14.2

Pawson, R. (2006) Evidence-Based Policy: A Realist Perspective, London: Sage Publications

Schwarzer, D.; Bloom, M. and Shono, S. (eds) (2006) Research as a Tool for Empowerment: Theory Informing Practice, Greenwich CT: Information Age Publishing

Sen, G. et al. (2017) 'Translating Health Research to Policy: Breaking through the Impermeability Barrier', in J. Georgalakis, N. Jessani, R. Oronje and B. Ramalingam (eds), The Social Realities of Knowledge for Development: Sharing Lessons of Improving Development Processes with Evidence, Brighton: IDS/Impact Initiative

Shucksmith, M. (2016) InterAction: How Can Academics and the Third Sector Work Together to Influence Policy and Practice?, Dunfermline: Carnegie UK Trust, www.issuelab.org/resource/interaction-how-can-academicsand-the-third-sector-work-together-to-influence-policy-and-practice. html (accessed 11 November 2018)

Tornay, S. (2009) 'Modernisation in the Lower Omo Valley and Adjacent Marches of Eastern Equatoria, Sudan: 1991-2000', in Günther Schlee and Elizabeth Watson (eds), Changing Identifications and Alliances in North-East Africa, Vol. 1: Ethiopia and Kenya, New York NY: Berghahn Books

Wessells, M. et al. (2017) 'How Collaboration, Early Engagement and Collective Ownership Increase Research Impact: Strengthening Community-Based Child Protection Mechanisms in Sierra Leone', in J. Georgalakis, N. Jessani, R. Oronje and B. Ramalingam (eds), The Social Realities of Knowledge for Development: Sharing Lessons of Improving Development Processes with Evidence, Brighton: IDS/Impact Initiative

Tewolde Woldemariam and Fana Gebresenbet (2014) 'Socio-Political and Conflict Implications of Sugar Development in Salamago Wereda, Ethiopia', in M.G. Berhe (ed.), A Delicate Balance: Land Use, Minority Rights and Social Stability in the Horn of Africa, Addis Ababa: Institute for Peace and Security Studies ${ }^{25}$

Teshome Yizengzaw (2005) 'Policy Development in Higher Education in Ethiopia and the Role of Donors and Development Partners', paper presented at the international expert meeting 'Formulas that Work: Making Higher Education Support More Effective', The Netherlands, 23-24 May, https://pdfs.semanticscholar. 
org/9cc5/263bbdd32d44aacf7d0d243af61c9362c15a.pdf (accessed 25 October 2018 $)^{26}$

Meles Zenawi (2011) Speech during the 13th Annual Pastoralists' Day Celebrations, Jinka, South Omo, 25 January, www.mursi.org/pdf/ Meles\%20Jinka\%20speech.pdf (accessed 14 March 2019)27 
